\title{
A survey of carbon sequestration potential of orchards and vineyards in Italy
}

\author{
F. Scandellari ${ }^{1}$, G. Caruso 2 , G. Liguori ${ }^{3}$, F. Meggio ${ }^{4}$, A.M. Palese ${ }^{5}$, D. Zanotelli ${ }^{1}$, G. Celano ${ }^{5}$, R. Gucci², \\ P. Inglese ${ }^{3}$, A. Pitacco ${ }^{4}$ and M. Tagliavini ${ }^{1}$ \\ 1 Faculty of Science and Technologies, Free University of Bolzano-Bozen, Bolzano, Italy \\ 2 Department of Agriculture, Food and Environment, University of Pisa, Pisa, Italy \\ 3 Dipartimento Scienze Agrarie e Forestali (SAF), University of Palermo, Palermo, Italy \\ ${ }^{4}$ Department of Agronomy, Food, Natural Resources, Animals and Environment - DAFNAE, University of Padova, Legnaro \\ (Padova), Italy \\ 5 Dipartimento delle Culture Europee e del Mediterraneo: Architettura, Ambiente, Patrimoni culturali (DiCEM), University of \\ Basilicata, Matera, Italy
}

\section{Summary}

Orchards and vineyards are important land use types in Southern Europe. In spite of their potential to sequester atmospheric $C$ and to mitigate climate change, relatively little is known regarding the influx and outflux of $\mathrm{C}$ in these systems. The aim of this work is to provide data on the $\mathrm{C}$ budget, including net primary production (NPP), C removal through production, and $C$ sequestration potential for the vineyards and the main fruit tree species (apple, citrus, olive, and peach) grown in Italy. Standing biomass and NPP were measured, and net ecosystem exchange and net $C$ balance assessed directly, through either eddy covariance technique, or considering NPP and heterotrophic respiration. Aboveground NPP ranged between 10 and $20 \mathrm{t} \mathrm{ha}^{-1}$ while, when directly assessed, belowground NPP was less than $20 \%$ of the total NPP. The $C$ leaving the system through fruit production ranged between 2 and $3 t^{h^{-1}}$. Mature fruit tree ecosystems had positive net ecosystem productivity (ranging

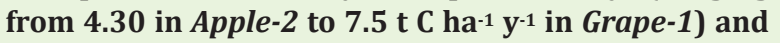
net ecosystem carbon balance (ranging from 0.6 to 5.9 t $\mathrm{Cha}^{-1} \mathrm{y}^{-1}$ ), indicating the potential of these systems to store $\mathrm{C}$.

Keywords

apple, carbon budget, citrus, grapevine, peach, olive, net primary production

\section{Introduction}

Atmospheric carbon in the form of carbon dioxide $\left(\mathrm{CO}_{2}\right)$, absorbed by plants via photosynthesis, is partially lost by the respiration process of green and non-green organs $\left(R_{a}\right)$. The remaining part is incorporated into organic compounds and partitioned to plant districts where it builds up the new biomass, which roughly represents the net primary production (NPP). Carbon (C) losses at the ecosystem level also occur because of the respiration of the heterotrophic organisms mainly present in the soil $\left(\mathrm{R}_{\mathrm{h}}\right)$. The difference between NPP and $\mathrm{R}_{\mathrm{h}}$ is an important ecological parameter (net ecosystem production, NEP) that indicates whether photosynthesis or respiration prevails, determining the potential of the ecosystem to become a net sink or a net source for carbon (Lovett

\section{Significance of this study}

What is already known on this subject?

- Fruit tree systems can fix significant amounts of carbon, but such potential has been largely unexplored.

What are the new findings?

- Above-ground production is relatively constant across systems. All mature systems store carbon over the considered period.

What is the expected impact on horticulture?

- Orchards and vineyards contribute negligibly to carbon emissions and this should be considered by policy makers.

et al., 2006). In agricultural systems, the gain or loss of carbon over time due to cultivation (net ecosystem $C$ balance, NECB) also depends on the amount of $\mathrm{C}$ entering (for example through organic amendments) and on that leaving the system (harvest of products).

In recent years, there has been an increasing interest on the $\mathrm{C}$ cycle in terrestrial ecosystems (Don et al., 2012; Eglin et al., 2010). In Europe, Janssens (2003) estimated that the biosphere is able to fix roughly $7-12 \%$ of anthropogenic emissions. Forests and grasslands are usually regarded as sinks for atmospheric C, while agricultural systems often act as sources of greenhouse gases (GHGs) due to soil disturbance, to biospheric fluxes of methane or nitrous oxide, and to field management involving direct (e.g., diesel fuel for machinery) or indirect (e.g., chemicals) emissions of fossil fuels (Ceschia et al., 2010). Climate change, induced by increasing atmospheric concentration of GHGs, therefore, urges to develop novel agricultural systems able to reduce emissions and to increase the potential of sequestering carbon in the biosphere (Pretty and Bharucha, 2014). Orchards and vineyards, in comparison with annual crops (Smaje, 2015), have structural characteristic allowing them to sequester significant quantities of atmospheric carbon, due to: i) their long life cycle, which allows them to accumulate $\mathrm{C}$ in permanent organs such as trunk, branches, and roots and in the soil through rhizodeposition; ii) a low or null soil tillage, which preserves soil organic matter from mineralization; iii) the 
frequent presence of herbaceous vegetation in the alleys, which can contribute to the buildup of soil organic matter. In addition, the growers' income for many widespread fruit crops (e.g., grape) is mainly due to the high quality more than the high quantity of yields; in other species (e.g., olive) yield limitations are inherent in the genetic potential of the crop. Crops with relatively low yields tend to partition less $\mathrm{C}$ to the fruits than high-yielding ones and, therefore, most NPP enters either the detritus cycle or is allocated to the tree frame (i.e. the permanent structures). In spite of the strategic role of orchards and vineyards in Southern Europe (Olesen and Bindi, 2002), their C fixation potential has been only partially explored. In Italy, fruit trees and vines cover more than 30\% of arable land in 2011 (FAOSTAT, 2015). In 2012 in the European Union, the main fruit tree crops (olive, grape, orange, peach and apple) accounted for about 3\% of total agricultural land area and for $11 \%$ of the gross production value of agricultural products (FAOSTAT, 2015).

The objective of this study is to provide quantitative data about the $\mathrm{C}$ budget at the ecosystem level, including NPP, C removal through production and $\mathrm{C}$ sequestration potential for the main fruit tree species grown in Italy. The work was undertaken within the frame of a national project aiming at studying the $\mathrm{C}$ cycle in managed tree ecosystems and used both original data and results from previously published individual studies (Caruso et al., 2013; Gucci et al., 2012; Liguori et al., 2009; Scandellari et al., 2010b; Zanotelli et al., 2013, 2015 ). We considered a range of species, tree ages, and environmental conditions that were representative of the variability inherent to perennial systems to estimate the potential of fruit tree ecosystems to fix C. On the other hand, this study did not aim at providing an exhaustive assessment of the $\mathrm{C}$ footprint related to the production of these agricultural systems since we did not consider the $\mathrm{C}$ emissions associated with orchard and vineyard management. This work partially fills the gap of knowledge on carbon fluxes in orchards and vineyards.

\section{Materials and methods}

\section{Plant material and site description}

This work was performed using perennial crop plantations that included a number of species, soils, climates and cultural conditions, as reported in Table 1. The species considered are among the most widely cultivated fruit crops in Europe (FAOSTAT, 2015) and the sites are representative of some of the most important areas of production in Italy. The two olive groves are located in Tuscany and in Basilicata (later referred as Olive-1 and Olive-2, respectively), the two apple orchards in Emilia Romagna and in South Tyrol (Apple-1 and Apple-2, respectively), the two orange orchards in Sicily (Citrus-1 and Citrus-2), the vineyards in Veneto and in Basilicata (Grape-1 and Grape-2, respectively), the peach orchard (Peach) in Basilicata (Table 1).

The study spanned the period 2006-2012. Long-term series of climatic data were averaged to characterize conditions for each site (Table 1). The reference evapotranspiration, $\mathrm{ET}_{0}$, was calculated from monthly temperatures using the Hargreaves-Samani model (Hargreaves and Samani, 1985). Soil texture, soil $\mathrm{pH}$, and soil organic matter (SOM) are also reported in Table 1 . Cultivars, rootstocks and main cultural practices for the studied orchards are reported in Table 2.

\section{Biomass determination}

The standing biomass of each orchard, expressed as dry weight (D.W.), was measured by tree excavations and/or by non-destructive techniques, as described for each orchard as follows. Where whole trees were harvested, they were divided into the main organs and their dry weight determined. Where specified, root dry weight was also measured. In Apple-1 and in Apple-2, total biomass and specific allometric equations were determined by excavating 13 trees in winter 2002-2003 and 2005-2006, and 11 trees in winter 2009-2010, respectively (Panzacchi et al., 2012; Scandellari et al., 2010; Zanotelli et al., 2013). In Citrus-1 and Citrus-2, total biomass was determined by excavating three trees at each site up to a depth of $150 \mathrm{~cm}$ in 2006. In Grape-1 (in winter 2007 and 2010) total biomass, including perennial above-ground and below-ground biomass, was determined when seven (2007) and nine (2010) vines were cut off and the above-ground biomass determined. The vines were uprooted to a depth of $60 \mathrm{~cm}$ and root biomass was determined.

In Grape-2, the total biomass of the whole plant was not measured. In Olive-1, the above-ground biomass was assessed on 24 fully productive trees by allometric measurements of the above-ground parts in 2012: in April 2012, one primary branch of six replicate trees was cut off at the point of insertion on the trunk, the biomass partitioned, and the relationship between dry weight and branch diameter estimated. Similarly, dry weight-wood diameter relationships were determined for 4 to 6 secondary branches per primary branch. In January 2013, the diameters of all the branches of 24 trees, including the six trees from which primary branches had been sampled destructively, were measured and their dry biomass estimated by using the regression equations previously calculated. The trunk biomass was estimated as the product of olive wood specific weight $\left(976 \mathrm{~kg} \mathrm{~m}^{-3}\right.$, value obtained from previous measurements in situ) by trunk volume, assuming a cylindrical shape. In Olive-2, the standing tree biomass was not measured. In Peach, the above-ground biomass of five trees was determined in 2004, 2005 and 2006 (winter period). In particular, fruit, pruned wood, and abscised leaves biomass was calculated through organs sampling, dry matter measurements and non-destructive measurements (measurements of volumetric and linear increase).

\section{Net primary production}

Net primary production was assessed by accounting the new biomass resulting from primary and secondary vegetative tree growth and fruit production. In Apple-1, aboveground net primary production (ANPP) was estimated on 3 trees in 2006. In Apple-2, ANPP was estimated on 6 trees in the period 2010-2012. In both orchards, the annual growth (in D.W.) of fruits, leaves, and shoots was directly measured. The secondary growth of branches and trunk was estimated from allometric relationships between trunk or branch circumference and their dry weight. Below-ground net primary production (BNPP) was assessed in the two apple orchards by integrating data of root density and root growth assessed with image analysis (Zanotelli et al., 2013) or by the sum of root growth and the carbon input from roots to soil (Panzacchi et al., 2012). In Citrus-1 and Citrus-2, ANPP was estimated on 4 or 3 trees, respectively, by summing the dry weight of abscised and harvested fruits, abscised leaves and current-year twigs and suckers and mown grasses. The annual growth of woody parts was estimated from allometric relationships between basal circumference of primary branches and the total dry weight of their subtended woody parts and non-destructive measurements at the beginning and at the end of 


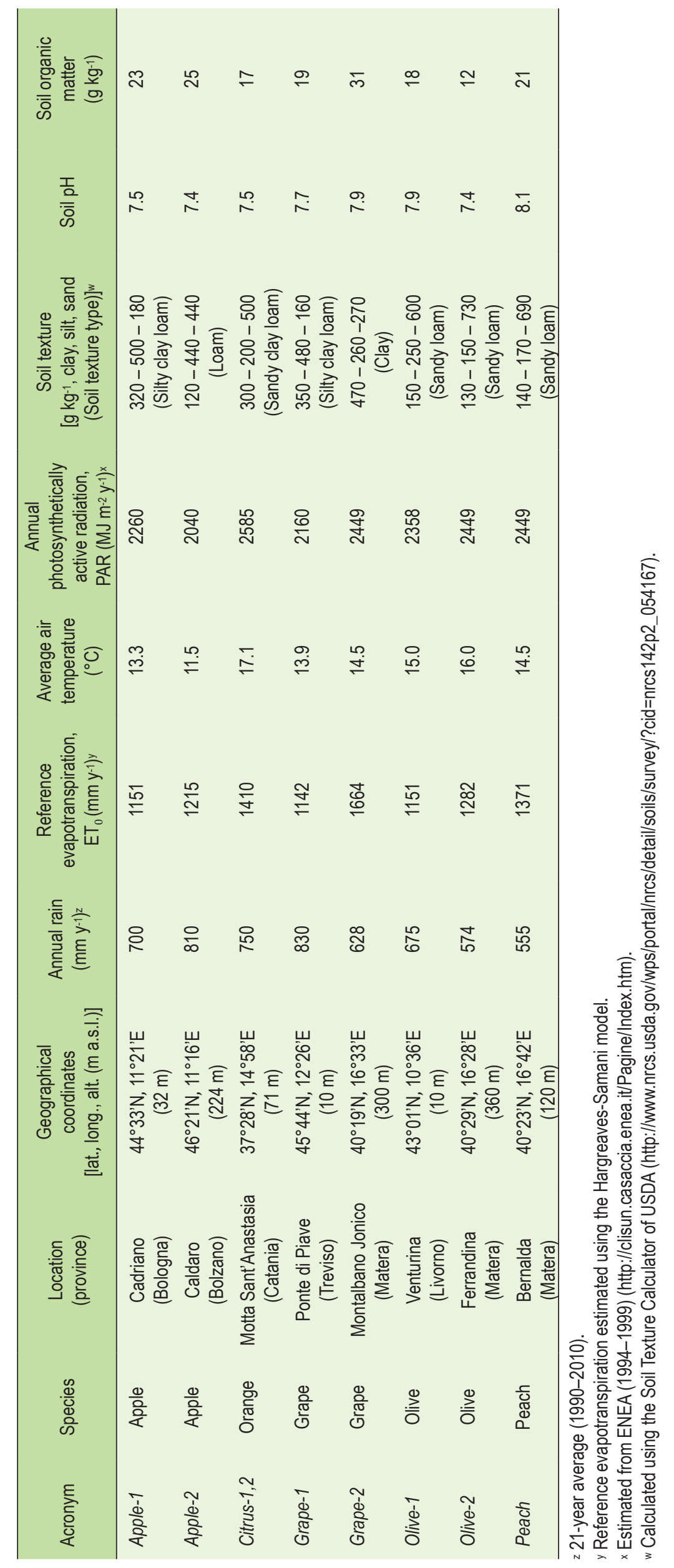


TABLE 2. Structural characteristics of the orchards and vineyards. Age, pruning wood and yield data refer to the year C fluxes were assessed. Pruning wood and yield are in fresh weight.

\begin{tabular}{|c|c|c|c|c|c|c|c|c|}
\hline Site & Cultivar & Rootstock & $\begin{array}{l}\text { Planting } \\
\text { year }\end{array}$ & $\begin{array}{c}\text { Density } \\
\text { (trees ha-1) }\end{array}$ & $\begin{array}{l}\text { Training } \\
\text { system }\end{array}$ & $\begin{array}{l}\text { Pruning wood } \\
\text { (t ha-1) }\end{array}$ & $\begin{array}{c}\text { Average } \\
\text { fruit yield } \\
\text { (t ha-1) }\end{array}$ & Reference \\
\hline Apple-1 & Gala & M9 & 1997 & 2632 & Spindlebush & 2.48 & 40 & Panzacchi et al. (2012) \\
\hline Apple-2 & Fuji & M9 & 2001 & 3300 & Spindlebush & 7.15 & 61 & $\begin{array}{l}\text { Zanotelli et al. (2013) } \\
\text { Zanotelli et al. (2015) }\end{array}$ \\
\hline Citrus-1 & Tarocco & Bitter orange & 1992 & 494 & Globe & 7.1 & 35 & Liguori et al. (2009) \\
\hline Citrus-2 & Newhall & Bitter orange & 1994 & 1000 & Globe & 4.1 & 40 & Liguori et al. (2009) \\
\hline Grape-1 & Carmenère & SO4 & 1992 & 3077 & $\begin{array}{l}\text { Moveable spur- } \\
\text { pruned cordon }\end{array}$ & 3.39 & 11 & Original data \\
\hline Grape-2 & Aglianico & P1103 & 2005 & 4444 & Spur cordon & 0.9 & 8 & Lardo (2012) \\
\hline Olive-1 & Frantoio & Self-rooted & 2003 & 513 & Free vase & 4.72 & 8.40 & $\begin{array}{l}\text { Caruso et al. (2013) } \\
\text { Gucci et al. (2012) }\end{array}$ \\
\hline Olive-2 & $\begin{array}{l}\text { Maiatica di } \\
\text { Ferrandina }\end{array}$ & Seedling & N.A.z & 156 & Vase & 6.7 & 9.7 & $\begin{array}{l}\text { Palese et al. (2013) } \\
\text { Lopez et al. (2006) } \\
\text { Palese et al. (2009) } \\
\text { Palese et al. (2012) }\end{array}$ \\
\hline Peach & Supercrimson & GF677 & 1997 & 500 & Vase & 8.1 & 25 & Original data \\
\hline
\end{tabular}

zN.A. = not available.

the growing season (Liguori et al., 2009). Below-ground NPP was not measured. In Grape-1, ANPP (in 2008) was estimated from measurements of annual dry biomass of fruit grape bunches, leaves and shoots of 15 selected vines. Annual trunk biomass increase was also assessed by the difference between trunk biomass determined in 2007 and in 2010. Below-ground NPP was not directly measured. In Grape-2, ANPP was estimated in the period 2009-2011. Yearly dry biomass of fruit grape bunches was measured on 40 plants, pruned material was measured on 20 plants, leaves and shoots were measured on 100 plants. The dry weight of the mown herbaceous vegetation was yearly measured from six plots of $1 \mathrm{~m}^{2}$ each. BNPP was not directly measured. In Olive-1, ANPP was estimated on 6 trees in 2012. Fruits were directly quantified at harvest. The secondary growth of primary branches and trunk was estimated from allometric relationships between trunk or branch circumference and their dry weight. The dry biomass of the understory was measured by periodically cutting the native grasses at ground level in nine plots of $1 \mathrm{~m}^{2}$ each, located in the inter-row (2.5 m from the tree line), and $0.8 \mathrm{~m}$ on opposite sides of the tree line. BNPP was not directly measured. In Olive-2, ANPP was estimated on 12 trees in the period 2001-2008. Pruned material and fruits were directly quantified. Senescent leaves, estimated as described before, were also included assuming that, due to tree age, the above-ground standing biomass was stable during that time interval. The dry weight of the mown herbaceous vegetation was measured on 6 plots of $1 \mathrm{~m}^{2}$ surface. BNPP was not measured. In Peach, ANPP was estimated on 3 trees in 2006. Pruned wood, senescent leaves, and fruits were directly quantified. The trunk biomass was estimated as difference between the standing tree biomass measured in 2005 and in 2006. In 2004, 2005 and 2006, the dry weight of the mown herbaceous vegetation of the orchard floor was measured from three plots of $1 \mathrm{~m}^{2}$ each. BNPP was not measured.

\section{Soil respiration}

Instantaneous measurements of soil respiration $\left(\mathrm{R}_{\mathrm{s}}\right)$ were recorded in Apple-1, Citrus-1, Citrus-2 and Olive-1 from representative areas of the orchard floor, to derive data of annual soil respiration. $R_{s}$ was recorded using an EGM-4 gas exchange system (PP Systems, Amesbury, MA, USA) equipped with a soil respiration chamber (SRC-1) and a soil temperature probe (STP-1) using PVC collars $(10 \mathrm{~cm}$ diameter, $12 \mathrm{~cm}$ high) inserted $8 \mathrm{~cm}$ into the soil, as reported by Ceccon et al. (2011) and Liguori et al. (2009). In Apple-1, soil respiration was measured at 16 positions, once a month in 2006 (Panzacchi et al., 2012); in Olive-1, 24 (from July 2010 to June 2011) or 30 (from June 2011 to November 2012) soil positions were measured approximately once a month; in Citrus-1 and Citrus-2, soil respiration was measured at 24 positions every two weeks from June 2005 to May 2006 (Liguori et al., 2009). Annual soil respiration values for each soil position were obtained assuming each measurement as representative for the period between two successive measurements. In Apple-1, the heterotrophic component of soil respiration $\left(\mathrm{R}_{\mathrm{h}}\right)$ was obtained by the trenching technique (Kuzyakov, 2006; Panzacchi et al., 2012).

\section{Net ecosystem budget calculations}

To convert dry biomass into amount of $\mathrm{C}$, the $\mathrm{C}$ concentration of plant samples used for NPP determination was analysed by an Elemental Analyzer, as previously reported (Panzacchi et al., 2012; Zanotelli et al., 2013), or by dry combustion method using the LECOSC230 apparatus (LECO Instruments, UK). Net ecosystem production (NEP, in t C ha-1) was calculated from eddy covariance data in Apple-2 (Zanotelli et al., 2013) and Grape-1 (Gianelle et al., 2015) sites, whereas it was estimated by subtracting $\mathrm{R}_{\mathrm{h}}$ values from NPP in Apple-1. Net ecosystem carbon balance (NECB) was calculated by subtracting the amount of $\mathrm{C}$ in the fruits from 
the NEP values and eventually adding the $\mathrm{C}$ contained in organic amendments distributed in the orchard.

\section{Results}

Above-ground biomass in winter, after winter pruning, was always higher than below-ground biomass with aboveground to below-ground ratios ranging from 1.2 (Citrus-1) to 4.6 (Grape-1). Above-ground biomass values were similar for peach, apple, and grape (Table 3 ). Citrus orchards showed the highest values of above-ground biomass, over 50 t D.W. ha $^{-1}$, whereas above-ground biomass of olive trees was 37 t D.W. ha ${ }^{-1}$. Total tree biomass in apple and grapevine ranged between 22.7 and 28.7 t D.W. ha-1. In citrus orchards, total biomass was markedly higher than in apple or grape (Table 3 ).

With the exception of Grape-2 and of Apple-2, the ANPP of trees was relatively consistent and ranged from 8.1 to 12.6 t C ha-1 $\mathrm{y}^{-1}$ (Table 3). On the contrary, the ANPP of the ground cover vegetation was variable across sites (Table 3 ). For instance, the ANPP of the ground cover vegetation in apple orchards (both located in Northern Italy) was 1.0-1.4 t ha-1 $\mathrm{y}^{-1}$, whereas values for other orchards in peninsular Italy or Sicily were much higher (Table 3). The relative contribution of the ground cover to orchard ANPP was less than $10 \%$ in the two apple orchards and in Grape-1, ranged between 24-28\% in Peach, Citrus-1, and Citrus-2 and Olive-1, and was even higher in Grape-2 and Olive-2 (Figure 1).

The amount of dry biomass allocated to fruits ranged from 2.9 to 10.2 t D.W. ha- ${ }^{-1} \mathrm{y}^{-1}$ for Grape-2 and Apple-2, respectively (Figure 1). The partitioning of tree ANPP into fruit was as high as 70\% for Grape-2, 59\% for Citrus-2, 58\% for Apple-2, 55\% for Citrus-2, 48\% for Olive-1 and for Olive-2, 47\% for Grape-1 and Apple-1, and 37\% for Peach-1 (data calculated from Figure 1). When the whole budget was considered, the partitioning of ANPP into tree framework (increment of tree standing biomass in Figure 1) varied from $3 \%$ ANPP in Grape-1 to 24\% ANPP in Apple-1, corresponding to 0.34 and 2.82 t D.W. ha- ${ }^{-1} \mathrm{y}^{-1}$, respectively. With the exception of Grape-2, the cumulative biomass of pruned wood and abscised leaves, both retuning to the soil, in the other sites ranged from 3.3 (in Olive-2) to 6.3 (in Peach) t D.W. ha-1 $\mathrm{y}^{-1}$ (Figure 1).

Annual values of $\mathrm{R}_{\mathrm{s}}$ were lowest in Apple-1, intermediate in the two citrus orchards and highest in the olive orchard (Table 4). NEP was always positive (Figure 2),

TABLE 3. Standing (determined in winter) above- and below-ground tree biomass, above-ground productivity of trees (tree ANPP) and of herbaceous vegetation (ground cover ANPP) (average \pm s.e.). Data are reported as dry weight. The number of replicates is reported in brackets.

\begin{tabular}{lccccc}
\hline Site & $\begin{array}{c}\text { Above-ground tree } \\
\text { biomass } \\
(\mathrm{t} \mathrm{ha-1})\end{array}$ & $\begin{array}{c}\text { Below-ground tree } \\
\text { biomass } \\
(\mathrm{t} \mathrm{ha-1})\end{array}$ & $\begin{array}{c}\text { Total tree } \\
\text { biomass } \\
(\mathrm{t} \mathrm{ha-1})\end{array}$ & $\begin{array}{c}\text { Tree } \\
\text { ANPP } \\
\left(\mathrm{t} \mathrm{ha}^{-1} \mathrm{y}^{-1}\right)\end{array}$ & $\begin{array}{c}\text { Ground cover } \\
\text { ANPP } \\
\left(\mathrm{t} \text { ha-1 } \mathrm{y}^{-1}\right)\end{array}$ \\
\hline Apple-1 & $17.00 \pm 7.50(13)$ & $10.50 \pm 4.90(13)$ & $28.70 \pm 12.50(13)$ & $11.81 \pm 0.56(3)$ & $1.03 \pm 0.06(3)$ \\
Apple-2 & $18.53 \pm 1.77(11)$ & $4.19 \pm 0.09(11)$ & $22.72 \pm 1.78(11)$ & $17.44 \pm 2.30(6)$ & $1.36 \pm 0.16(6)$ \\
Citrus-1 & $56.53 \pm 1.95(3)$ & $45.95 \pm 2.05(3)$ & $106.48 \pm 4.00(3)$ & $11.88 \pm 2.90(4)$ & $5.29 \pm 0.24(3)$ \\
Citrus-2 & $51.60 \pm 1.31(3)$ & $29.54 \pm 1.96(3)$ & $81.14 \pm 2.42(3)$ & $12.60 \pm 3.27(3)$ & $4.10 \pm 0.52(3)$ \\
Grape-1 & $19.46 \pm 1.48(7)$ & $4.26 \pm 0.15(7)$ & $23.72 \pm 1.63(7)$ & $9.96 \pm 0.82(15)$ & $0.48 \pm 0.01(4)$ \\
Grape-2 & N.A.z & N.A. & N.A. & $4.58 \pm 1.12(20)$ & $6.52 \pm 2.40(3)$ \\
Olive-1 & $36.97 \pm 4.80(6)$ & N.A. & N.A. & $10.35 \pm 1.20(6)$ & $4.20 \pm 0.50(9)$ \\
Olive-2 & N.A. & N.A. & N.A. & $8.10 \pm 0.70(4)$ & $6.26 \pm 2.20(3)$ \\
Peach & $19.49 \pm 2.38(5)$ & N.A. & N.A. & $9.94 \pm 1.47(5)$ & $3.65 \pm 2.16(3)$ \\
\hline
\end{tabular}

zN.A. = not available.

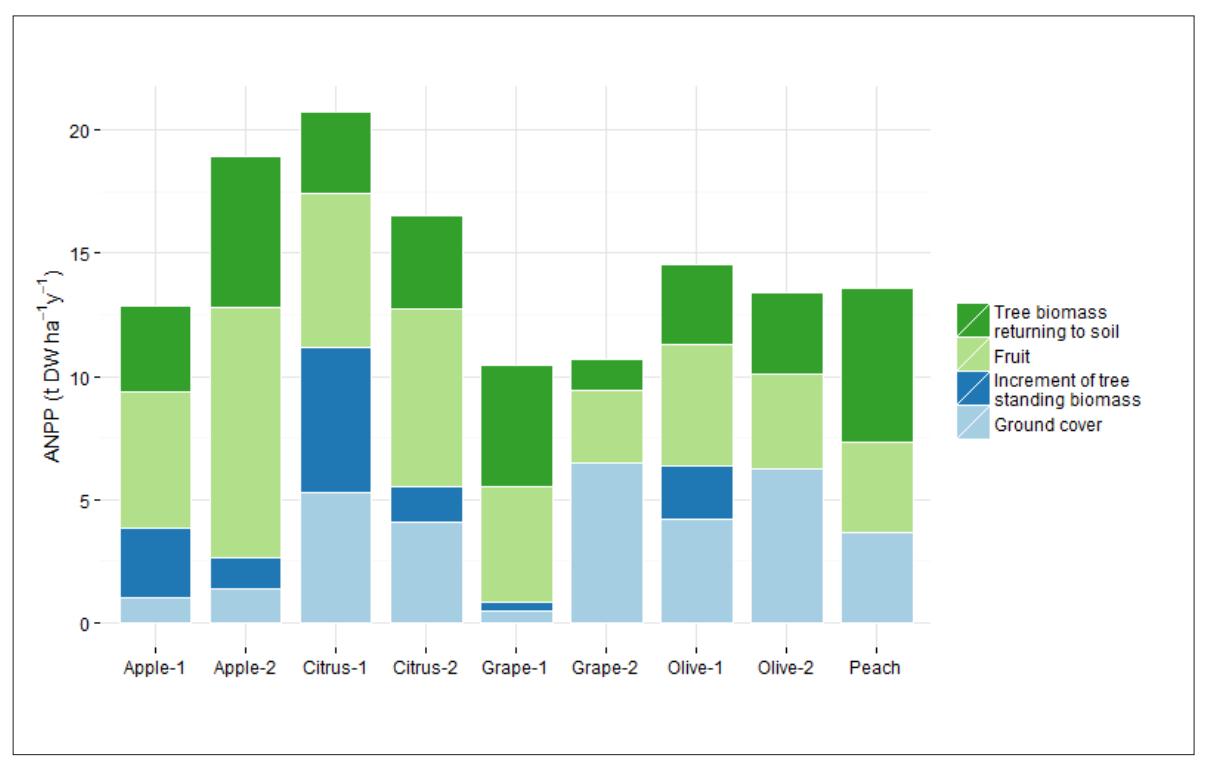

FiguRE 1. Partitioning of above-ground net primary production (ANPP) among ground cover vegetation, tree biomass returning to soil (pruned wood and leaves), and biomass allocated to tree framework and fruit, in the study sites. 


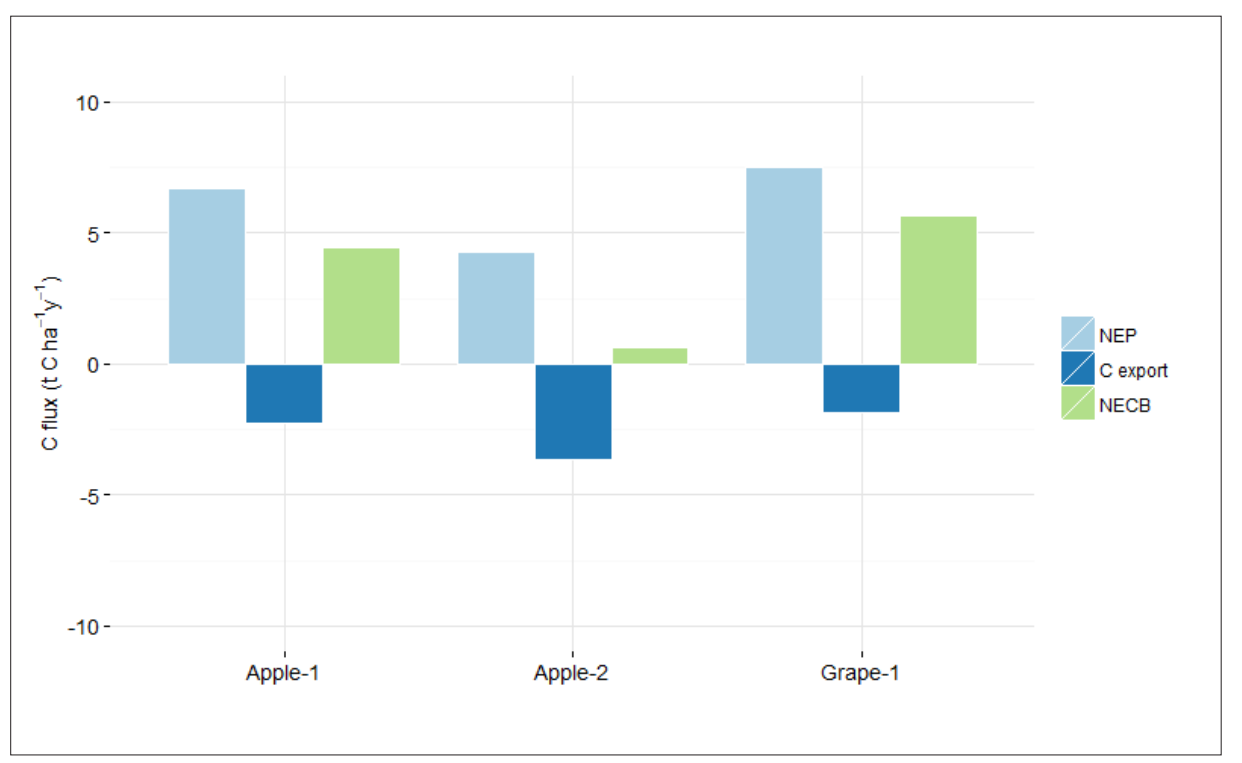

FiguRE 2. Net ecosystem production (NEP), indicated as a net positive flux entering the system, amount of $\mathrm{C}$ in the harvested fruits (C export), indicated as a net negative flux leaving the system, and net ecosystem $\mathrm{C}$ balance (NECB). NEP was obtained by eddy covariance techniques in Apple-2 and Grape- 1 and by subtracting $\mathrm{R}_{\mathrm{h}}$ to NPP in Apple-1.

TABLE 4. Annual values of soil respiration $\left(R_{s}\right)$.

Data are in $\mathrm{g} \mathrm{C} \mathrm{m}^{-2} \mathrm{y}^{-1}$ and represent average \pm s.e.

\begin{tabular}{lcc}
\hline Site & $\begin{array}{c}\mathrm{R}_{\mathrm{s}} \\
\left(\mathrm{g} \mathrm{C} \mathrm{m}^{-2} \mathrm{y}^{-1}\right)\end{array}$ & Reference \\
\hline Apple-1 & $228 \pm 9$ & Panzacchi et al. (2012) \\
Citrus-1 & $590 \pm 41$ & Liguori et al. (2009) \\
Citrus-2 & $420 \pm 34$ & Liguori et al. (2009) \\
Olive-1 & $895 \pm 119$ & - \\
\hline
\end{tabular}

with values ranging from $4.3 \mathrm{t} \mathrm{C} \mathrm{ha-1} \mathrm{per} \mathrm{year} \mathrm{for} \mathrm{Apple-2} \mathrm{or-}$ chard to $7.5 \mathrm{t} \mathrm{C} \mathrm{ha-1} \mathrm{per} \mathrm{year} \mathrm{for} \mathrm{Grape-1} \mathrm{(Figure} \mathrm{2),} \mathrm{while} \mathrm{the}$ amount of $\mathrm{C}$ allocated to fruits was highest in Apple-2 (>3 t C ha $^{-1}$ ) and lowest in Grape-1 (1.9 t C ha-1 (Figure 2). NECB, that is the difference between NEP and fruit $C$ export, was positive in both apple orchards and in the vineyard.

\section{Discussion}

In recent years the carbon budget of fruit tree plantations has received increasing attention with studies conducted in olive (Nardino et al., 2013; Sofo et al., 2005), palm (Navarro et al., 2008), apple (Zanotelli et al., 2015), peach (Sofo et al., 2005), and pear (Zhang et al., 2013). However, unlike other systems such as croplands (Ceschia et al., 2010; Smith, 2004), grasslands (Derner and Schuman, 2007; O'Mara, 2012) and forests (Barr et al., 2002; Vogt, 1991), there are no published studies comparing the ability of different perennial fruit tree plantations to fix atmospheric C. In our survey, the cumulative annual ecosystem ANPP of mature tree plantations approximately ranged from 10 (in grape) to 20 (in apple and citrus) $\mathrm{t} \mathrm{ha}^{-1}$ (Table 3). When BNPP was measured, such as in the Apple-2 orchard (Zanotelli et al., 2015), it accounted for less than $20 \%$ of total NPP, similarly to the value reported for a rain-fed olive grove in Murcia (Almagro et al., 2010). The highest values of yearly produced biomass (close to $20 \mathrm{t} \mathrm{ha}^{-1}$ ) measured in this study were similar to those reported for temperate forests (Luyssaert et al., 2007), traditional olive groves (Almagro et al., 2010), and for sugar beet, maize, rice and, sometimes, for wheat (Ceschia et al., 2010), while the lowest values (approx. $10 \mathrm{t} \mathrm{ha}^{-1}$ ) were similar to those reported for barley and rapeseed (Ceschia et al., 2010).
Trees and herbaceous species present in the orchard alleys contributed differently to ANPP according to the crop and the location. Tree growth accounted for most ANPP at all sites, except for the young vineyard Grape-2, where more biomass was produced by the ground cover vegetation than by vines. In general, the contribution of the ground cover to ecosystem ANPP was markedly higher in the sites located in Central or Southern Italy (Citrus-1 and -2, Grape-2, Olive-1 and -2 , Peach; Table 3 and Figure 1), probably because of the milder climate and higher radiation values enjoyed by the herbaceous vegetation of the orchard floor (Table 1). In Northern Italy (Grape-1 and Apple-1 and Apple-2), low temperatures usually inhibit plant growth in winter months.

The amount of $\mathrm{C}$ allocated to fruits, and therefore leaving the ecosystem after fruit harvest, varied among the species and was obviously influenced by yields as well as by the fruit $\mathrm{C}$ content. With the exception of the two apple orchards located in Northern Italy, where exceptionally high harvest indexes were measured and most $\mathrm{C}$ left the system as fruit, a significant fraction of the $\mathrm{C}$ allocated to above-ground organs returned to the soil as abscised leaves, pruned material of trees and mown herbaceous plants. In our study, we could not provide quantitative evidence of the $\mathrm{C}$ flux to the soil deriving from annual rhizodeposition of tree, weed and grass roots, although this process is well known to significantly contribute to the detritus cycle (Grayston et al., 1997; Nie et al., 2011; Scandellari et al., 2010a; Martinez et al., 2016). This fact may have caused an underestimation of the amount of $C$ stored in the soil. Pruned wood, abscised leaves and mown vegetation also differently contribute to the $C$ storage, due to the different annual biomass and to the different decomposition dynamics: the cut material resulting from grasses and legumes releases more than $50 \%$ of its $\mathrm{C}$ content within two months from mowing, and more than $70 \%$ within four months (Brunetto et al., 2011). On the contrary, apple leaf litter releases its carbon more slowly (Tagliavini et al., 2007). To be fully decomposed, leaf litter may need either one year in warm climates of Southern Italy (Liguori et al., 2009) or up to three years in the colder environments of Northern Italy (Tagliavini et al., 2007; Ventura et al., 2009). Almagro et al. (2010) reported high rates of litter decomposition for rosemary and olive material, but low rates for Aleppo pine under Mediterranean climate conditions. 
Both when NEP was directly assessed by eddy covariance (Apple-2 and Grape-1) and when it was calculated based on NPP and $\mathrm{R}_{\mathrm{h}}$ (Apple-1), the fruit tree plantations showed positive values of NEP and NECB. Both NEP and NECB were also likely positive in Citrus-1 and Citrus- 2 as it would appear from the fact that, even without considering BNPP, ANPP data shown in Table 3 and adjusted for an average $C$ concentration of $44 \%$ (Scandellari et al., in press) largely overcome the heterotrophic component of soil respiration $R_{h}$, if the latter is assumed equal to $65 \%$ of the $\mathrm{R}_{\mathrm{s}}$ vaues of Table 4 (Subke et al., 2006; Ceccon et al., 2011; Panzacchi et al., 2012; Zanotelli et al., 2013). Similarly, based on ANPP only, in the Olive-1 orchard, NEP would appear positive, but lower than C export to fruits. In this site, NECB would anyway become positive if BNPP were at least $20 \%$ of ANPP values.

NEP represents the net carbon gain, if positive, or loss, if negative, occurring during the production cycle (that is the difference between gross primary production, GPP, and ecosystem respiration, $\mathrm{R}_{\text {eco }}$ ), while NECB expresses the ability of the system to gain or lose its $C$ content over the years. Positive values of NEP are stimulated by high leaf photosynthetic rates, high $\mathrm{C}$ use efficiencies, and low heterotrophic respiration rates. On the other hand, positive values of NECB, besides being affected by all factors modulating NEP, also depend on lateral C fluxes (IPCC, 2000), like those resulting from the soil addition of organic fertilisers or amendments or from the $\mathrm{C}$ export with fruit yields.

The positive values of NECB indicate the inherent ability of tree plantations to store $\mathrm{C}$ over time in the above- and below-ground woody organs and/or in the soil as a consequence of carbon input associated with pruned wood, abscised leaves and mown grasses (Figure 1). In this respect, the tree plantations used in our study differ from many grain crops, that, due to harvest indexes normally in the range of 0.4-0.6 (Hay, 1995), show C export with yields often higher than NEP (Ceschia et al., 2010). In our survey, similar values of NECB between the different species are the result of different intensity of $\mathrm{C}$ influx and outflux. For instance, Apple-2 had lower NECB than Apple-1 and Grape-1 in spite of higher NPP values, likely because of higher soil heterotrophic respiration (as NEP data in Figure 2 would indicate) and higher $\mathrm{C}$ export by fruits. By monitoring for four consecutive years the NECB of Apple-2 orchard, Zanotelli et al. (2015) showed that only when yields were exceptionally high (i.e., because of high fruit set and insufficient fruit thinning), the NECB becomes negative and the orchard acts as a source of $\mathrm{C}$ to the atmosphere. A positive yearly ecosystem $\mathrm{C}$ storage may be due to either the increase of the standing biomass of trees and herbaceous vegetation and/or to the increase of the soil organic matter resulting from $\mathrm{C}$ inputs to the soil. The $\mathrm{C}$ accumulation in the tree standing biomass (Figure 1) accounted for the majority or even the entire amount of NECB (Figure 2 ) in several of the studied systems. The ecosystem residence of the $\mathrm{C}$ in the tree framework depends on the duration of the planting, which may range from 20 years for apple to 40 years for grape, and even longer for olive. When the orchard is uprooted at the end of the economic cycle, the fate of this $\mathrm{C}$ depends on the destination of such biomass.

In conclusion, we showed that despite the variability of standing biomass and ground cover ANPP, the tree ANPP was relatively stable, regardless of the plantation types (with the exception of Apple-2 and Grape-2) and environmental conditions. The values of NEP and NECB are valuable preliminary information on parameters needed to calculate the contributions of fruit tree plantation to the $\mathrm{C}$ emissions or uptake.
The relevance of the present study is to provide first-hand information that can be used by policy makers and professional organizations. This work is obviously not conclusive, as it should be integrated with similar survey studies across other sites or regions in Southern Europe. However, these first results show that orchards and vineyards positively contribute to alleviate $\mathrm{C}$ emissions into the atmosphere.

\section{Acknowledgments}

This research was funded in 2004 (project "Carbon cycle in managed tree ecosystems"; project n. 2004074422) and in 2008 (project "Carbon cycle in managed tree ecosystems"; project $n$. 2008LX3AYP) by the Italian Ministry for University and Research (MIUR) through the program Programmi di Ricerca Scientifica di Rilevante Interesse Nazionale (PRIN).

\section{References}

Almagro, M., López, J., Boix-Fayos, C., Albaladejo, J., and MartínezMena, M. (2010). Belowground carbon allocation patterns in a dry Mediterranean ecosystem: A comparison of two models. Soil Biol. Biochem. 42, 1549-1557. http://dx.doi.org/10.1016/j. soilbio.2010.05.031.

Barr, A.G., Griffis, T.J., Black, T.A., Lee, X., Staebler, R.M., Fuentes, J.D., Chen, Z., and Morgenstern, K. (2002). Comparing the carbon budgets of boreal and temperate deciduous forest stands. Can. J. For. Res. 32, 813-822. http://dx.doi.org/10.1139/x01-131.

Brunetto, G., Ventura, M., Scandellari, F., Ceretta, C.A., Kaminski, J., Melo, G.W., and Tagliavini, M. (2011). Nutrient release during the decomposition of mowed perennial ryegrass and white clover and its contribution to nitrogen nutrition of grapevine. Nutr. Cycl. Agroecosystems 90, 299-308. http://dx.doi.org/10.1007/s10705011-9430-8.

Caruso, G., Rapoport, H.F., and Gucci, R. (2013). Long-term evaluation of yield components of young olive trees during the onset of fruit production under different irrigation regimes. Irrig. Sci. 31, 37-47. http://dx.doi.org/10.1007/s00271-011-0286-0.

Ceccon, C., Panzacchi, P., Scandellari, F., Prandi, L., Ventura, M., Russo, B., Millard, P., and Tagliavini, M. (2011). Spatial and temporal effects of soil temperature and moisture and the relation to fine root density on root and soil respiration in a mature apple orchard. Plant Soil 342, 195-206. http://dx.doi.org/10.1007/s11104-010-0684-8.

Ceschia, E., Béziat, P., Dejoux, J.F., Aubinet, M., Bernhofer, C., Bodson, B., Buchmann, N., Carrara, A., Cellier, P., Di Tommasi, P., Elbers, J.A., Eugster, W., Grünwald, T., Jacobs, C.M.J., Jans, W.W.P., Jones, M., Kutsch, W., Lanigan, G., Magliulo, E., Marloie, O., Moors, E.J., Moureaux, C., Olioso, A., Osborne, B., Sanz, M.J., Saunders, M., Smith, P., Soegaard, H., and Wattenbach, M. (2010). Management effects on net ecosystem carbon and GHG budgets at European crop sites. Agric. Ecosyst. Environ. 139, 363-383. http://dx.doi.org/10.1016/j. agee.2010.09.020.

Derner, J.D., and Schuman, G.E. (2007). Carbon sequestration and rangelands: A synthesis of land management and precipitation effects. J. Soil Water Conserv. 62, 77-85.

Don, A., Osborne, B., Hastings, A., Skiba, U., Carter, M.S., Drewer, J., Flessa, H., Freibauer, A., Hyvonen, N., Jones, M.B., Lanigan, G.J., Mander, U., Monti, A., Djomo, S.N., Valentine, J., Walter, K., ZegadaLizarazu, W., and Zenone, T. (2012). Land-use change to bioenergy production in Europe: implications for the greenhouse gas balance and soil carbon. Glob. Change Biol. Bioenergy 4, 372-391. http:// dx.doi.org/10.1111/j.1757-1707.2011.01116.x.

Eglin, T., Ciais, P., Piao, S.L., Barre, P., Bellassen, V., Cadule, P., Chenu, C., Gasser, T., Koven, C., Reichstein, M., and Smith, P. (2010). Historical and future perspectives of global soil carbon response to climate and land-use changes. Tellus Ser. B-Chem. Phys. Meteorol. 62, 700-718. http://dx.doi.org/10.1111/j.1600-0889.2010.00499.x. 
FAOSTAT (2015). Retrieved May 14, 2015, from http://faostat3.fao. org/home/E.

Gianelle, D., Gristina, L., Pitacco, A., Spano, D., La Mantia, T., Marras, S., Meggio, F., Novara, A., Sirca, C., and Sottocornola, M. (2015). The role of vineyards in the carbon balance throughout Italy. In The greenhouse gas balance of Italy, Environmental science and engineering, R. Valentini, and F. Miglietta, eds. (Berlin, Heidelberg: Springer). pp. 159-171. http://dx.doi.org/10.1007/978-3-64232424-6_11.

Grayston, S.J., Vaughan, D., and Jones, D. (1997). Rhizosphere carbon flow in trees, in comparison with annual plants: the importance of root exudation and its impact on microbial activity and nutrient availability. Appl. Soil Ecol. 5, 29-56. http://dx.doi.org/10.1016/ S0929-1393(96)00126-6.

Gucci, R., Caruso, G., Bertolla, C., Urbani, S., Taticchi, A., Esposto, S., Servili, M., Sifola, M.I., Pellegrini, S., Pagliai, M., and Vignozzi, N. (2012). Changes of soil properties and tree performance induced by soil management in a high-density olive orchard. Eur. J. Agron. 41, 18-27. http://dx.doi.org/10.1016/j.eja.2012.03.002.

Hargreaves, G.H., and Samani, Z.A. (1985). Reference crop evapotranspiration from temperature. Appl. Eng. Agric. 1, 96-99. http://dx.doi.org/10.13031/2013.26773.

Hay, R.K.M. (1995). Harvest index: a review of its use in plant breeding and crop physiology. Ann. Appl. Biol. 126, 197-216. http:// dx.doi.org/10.1111/j.1744-7348.1995.tb05015.x.

IPCC (2000). Land Use, Land-Use Change, and Forestry. R.T. Watson, I.R. Noble, B. Bolin, N.H. Ravindranath, D.J. Verardo, and D.J. Dokken, eds. (UK: Cambridge University Press). pp. 375

Janssens, I.A. (2003). Europe's terrestrial biosphere absorbs 7 to $12 \%$ of European anthropogenic $\mathrm{CO}_{2}$ emissions. Science 300, 15381542. http://dx.doi.org/10.1126/science.1083592.

Kuzyakov, Y. (2006). Sources of $\mathrm{CO}_{2}$ efflux from soil and review of partitioning methods. Soil Biol. Biochem. 38, 425-448. http://dx.doi. org/10.1016/j.soilbio.2005.08.020.

Lardo, E. (2012). Study of carbon cycle and environmental sustainability in the vineyard systems for quality wine production Crop systems, forestry and environmental sciences. (PhD Thesis, International PhD School).

Liguori, G., Gugliuzza, G., and Inglese, P. (2009). Evaluating carbon fluxes in orange orchards in relation to planting density. J. Agric. Sci. 147, 637. http://dx.doi.org/10.1017/S002185960900882X.

Lopez, A., Pollice, A., Lonigro, A., Masi, S., Palese, A.M., Cirelli, G.L., Toscano, A., and Passino, R. (2006). Agricultural wastewater reuse in Southern Italy. Desalination 187, 323-334. http://dx.doi. org/10.1016/j.desal.2005.04.091.

Lovett, G.M., Cole, J.J., and Pace, M.L. (2006). Is net ecosystem production equal to ecosystem carbon accumulation? Ecosystems 9, 152-155. http://dx.doi.org/10.1007/s10021-005-0036-3.

Luyssaert, S., Inglima, I., Jung, M., Richardson, A.D., Reichstein, M., Papale, D., Piao, S.L., Schulze, E.-D., Wingate, L., Matteucci, G., Aragao, L., Aubinet, M., Beer, C., Bernhofer, C., Black, K.G., Bonal, D., Bonnefond, J.-M., Chambers, J., Ciais, P., Cook, B., Davis, K.J., Dolman, A.J., Gielen, B., Goulden, M., Grace, J., Granier, A., Grelle, A., Griffis, T., Grünwald, T., Guidolotti, G., Hanson, P.J., Harding, R., Hollinger, D.Y., Hutyra, L.R., Kolari, P., Kruijt, B., Kutsch, W., Lagergren, F., Laurila, T., Law, B.E., Le Maire, G., Lindroth, A., Loustau, D., Malhi, Y., Mateus, J., Migliavacca, M., Misson, L., Montagnani, L., Moncrieff, J., Moors, E., Munger, J.W., Nikinmaa, E., Ollinger, S.V., Pita, G., Rebmann, C., Roupsard, O., Saigusa, N., Sanz, M.J., Seufert, G., Sierra, C., Smith, M.-L., Tang, J., Valentini, R., Vesala, T., and Janssens, I.A. (2007). $\mathrm{CO}_{2}$ balance of boreal, temperate, and tropical forests derived from a global database. Glob. Change Biol. 13, 2509-2537. http://dx.doi. org/10.1111/j.1365-2486.2007.01439.x.
Martinez, C., Alberti, G., Cotrufo, M.F., Magnani, F., Zanotelli, D., Camin, F., Gianelle, D., Cescatti, A., and Rodeghiero, M. (2016). Belowground carbon allocation patterns as determined by the in-growth soil ${ }^{13} \mathrm{C}$ technique across different ecosystem types. Geoderma 263, 140150. http://dx.doi.org/10.1016/j.geoderma.2015.08.043.

Nardino, M., Pernice, F., Rossi, F., Georgiadis, T., Facini, O., Motisi, A., and Drago, A. (2013). Annual and monthly carbon balance in an intensively managed Mediterranean olive orchard. Photosynthetica 51, 63-74. http://dx.doi.org/10.1007/s11099-012-0079-6.

Navarro, M.N.V., Jourdan, C., Sileye, T., Braconnier, S., Mialet-Serra, I., Saint-Andre, L., Dauzat, J., Nouvellon, Y., Epron, D., Bonnefond, J.M., et al. (2008). Fruit development, not GPP, drives seasonal variation in NPP in a tropical palm plantation. Tree Physiol. 28, 1661-1674. http://dx.doi.org/10.1093/treephys/28.11.1661.

Nie, S., Ge, T., Liu, C., and Xiao, H. (2011). Crop-assimilative carbon in the farmland ecosystem - an important source for carbon turnover in soil. Acta Agric. Scand. Sect. B-Soil Plant Sci. 61, 105-111. http:// dx.doi.org/10.1080/09064711003670862.

O'Mara, F.P. (2012). The role of grasslands in food security and climate change. Ann. Bot. 110, 1263-1270. http://dx.doi.org/10.1093/aob/ mcs209.

Olesen, J.E., and Bindi, M. (2002). Consequences of climate change for European agricultural productivity, land use and policy. Eur. J. Agron. 16, 239-262. http://dx.doi.org/10.1016/S1161-0301(02)00004-7.

Palese, A.M., Pasquale, V., Celano, G., Figliuolo, G., Masi, S., and Xiloyannis, C. (2009). Irrigation of olive groves in Southern Italy with treated municipal wastewater: effects on microbiological quality of soil and fruits. Agriculture, Ecosystems \& Environment 129, 43-51. http://dx.doi.org/10.1016/j.agee.2008.07.003.

Palese, A.M., Celano, G., and Xiloyannis, C. (2012). Esigenze Minerali e Tecniche di Concimazione - Collana divulgativa dell'Accademia, Vol. X (Spoleto: Accademia Nazionale dell'Olivo e dell'Olio). pp. 1-26.

Palese, A.M., Pergola, M., Favia, M., Xiloyannis, C., and Celano, G. (2013). A sustainable model for the management of olive orchards located in semi-arid marginal areas: some remarks and indications for policy makers. Environmental Science and Policy 27, 81-90. http://dx.doi.org/10.1016/j.envsci.2012.11.001.

Panzacchi, P., Tonon, G., Ceccon, C., Scandellari, F., Ventura, M., Zibordi, M., and Tagliavini, M. (2012). Belowground carbon allocation and net primary and ecosystem productivities in apple trees (Malus domestica) as affected by soil water availability. Plant Soil 360, 229241. http://dx.doi.org/10.1007/s11104-012-1235-2.

Pretty, J., and Bharucha, Z.P. (2014). Sustainable intensification in agricultural systems. Ann. Bot. 114, 1571-1596. http://dx.doi. org/10.1093/aob/mcu205.

Scandellari, F., Liguori, G., Caruso, G., Meggio, F., Inglese, P., Gucci, R., Pitacco, A., Celano, G. and Tagliavini, M. (in press) Carbon sequestration potential of Italian orchards and vineyards, Proceedings of the International ISHS Symposium on physiological principles and their application to fruit production, Geneva, USA. Acta Horticulturae (in press).

Scandellari, F., Ventura, M., Gioacchini, P., Vittori Antisari, L., and Tagliavini, M. (2010a). Seasonal pattern of net nitrogen rhizodeposition from peach (Prunus persica (L.) Batsch) trees in soils with different textures. Agric. Ecosyst. Environ. 136, 162-168. http://dx.doi.org/10.1016/j.agee.2009.12.017.

Scandellari, F., Ventura, M., Malaguti, D., Ceccon, C., Menarbin, G., and Tagliavini, M. (2010b). Net primary productivity and partitioning of absorbed nutrients in field-grown apple trees. Acta Hortic. 868, 115-122. http://dx.doi.org/10.17660/actahortic.2010.868.11. 
Smaje, C. (2015). The strong perennial vision: A critical review. Agroecol. Sustain. Food Syst. 39, 471-499. http://dx.doi.org/10.10 80/21683565.2015.1007200.

Smith, P. (2004). Carbon sequestration in croplands: the potential in Europe and the global context. Eur. J. Agron. 20, 229-236. http:// dx.doi.org/10.1016/j.eja.2003.08.002.

Sofo, A., Nuzzo, V., Palese, A.M., Xiloyannis, C., Celano, G., Zukowskyj, P., and Dichio, B. (2005). Net $\mathrm{CO}_{2}$ storage in Mediterranean olive and peach orchards. Sci. Hortic. 107, 17-24. http://dx.doi.org/10.1016/j. scienta.2005.06.001.

Subke, J.-A., Inglima, I., and Francesca Cotrufo, M. (2006). Trends and methodological impacts in soil $\mathrm{CO}_{2}$ efflux partitioning: A metaanalytical review. Glob. Change Biol. 12, 921-943. http://dx.doi. org/10.1111/j.1365-2486.2006.01117.x.

Tagliavini, M., Tonon, G., Scandellari, F., Quiñones, A., Palmieri, S., Menarbin, G., Gioacchini, P., and Masia, A. (2007). Nutrient recycling during the decomposition of apple leaves (Malus domestica) and mowed grasses in an orchard. Agric. Ecosyst. Environ. 118, 191-200. http://dx.doi.org/10.1016/j.agee.2006.05.018.

Ventura, M., Scandellari, F., Bonora, E., and Tagliavini, M. (2009). Nutrient release during decomposition of leaf litter in a peach (Prunus persica L.) orchard. Nutr. Cycl. Agroecosystems 87, 115-125. http://dx.doi.org/10.1007/s10705-009-9317-0.

Vogt, K. (1991). Carbon budgets of temperate forest ecosystems. Tree Physiol. 9, 69-86. http://dx.doi.org/10.1093/treephys/9.1-2.69.

Zanotelli, D., Montagnani, L., Manca, G., and Tagliavini, M. (2013). Net primary productivity, allocation pattern and carbon use efficiency in an apple orchard assessed by integrating eddy covariance, biometric and continuous soil chamber measurements. Biogeosciences 10, 3089-3108. http://dx.doi.org/10.5194/bg-10-3089-2013.

Zanotelli, D., Montagnani, L., Manca, G., Scandellari, F., and Tagliavini, M. (2015). Net ecosystem carbon balance of an apple orchard. Eur. J. Agron. 63, 97-104. http://dx.doi.org/10.1016/j.eja.2014.12.002.

Zhang, Y., Shen, Y., Xu, X., Sun, H., Li, F., and Wang, Q. (2013). Characteristics of the water-energy-carbon fluxes of irrigated pear (Pyrus bretschneideri Rehd) orchards in the North China Plain. Agric. Water Manag. 128, 140-148. http://dx.doi.org/10.1016/ j.agwat.2013.07.007.

Received: Oct. 16, 2015

Accepted: Mar. 6, 2016

Addresses of authors:

Francesca Scandellari1, Giovanni Caruso2 ${ }^{2}$, Giorgia Liguori3 ${ }^{3}$, Franco Meggio ${ }^{4}$, Assunta Maria Palese 5, Damiano Zanotelli1, Giuseppe Celano5, Riccardo Gucci2,**, Paolo Inglese ${ }^{3}$, Andrea Pitacco $^{4}$ and Massimo Tagliavini 1 ,*

1 Faculty of Science and Technologies, Free University of Bolzano-Bozen, Piazza Università 5, 39100 Bolzano, Italy

2 Department of Agriculture, Food and Environment, University of Pisa, Via del Borghetto 80, 56124 Pisa, Italy

3 Dipartimento Scienze Agrarie e Forestali (SAF), Viale delle Scienze, University of Palermo, 90128 Palermo, Italy

4 Department of Agronomy Food Natural Resources Animals and Environment - DAFNAE, University of Padova, Agripolis, Viale dell'Università 16, 35020 Legnaro (Padova), Italy ${ }^{5}$ Dipartimento delle Culture Europee e del Mediterraneo: Architettura, Ambiente, Patrimoni culturali (DiCEM), University of Basilicata, Via San Rocco 3, 75100 Matera, Italy
Corresponding authors:

*E-mail: massimo.tagliavini@unibz.it

Tel.: +390471 017120; Fax: +390471017009

** E-mail: riccardo.gucci@unipi.it

Tel.: +39050 2216138; Fax: +390502216147 